strains are third generation cephalosporins and ciprofloxacin. Surgical intervention in the form of vegetectomy, valve replacement or embolectomy is often necessary in cases of $H$ parainfluenzae endocarditis. ${ }^{28}$

Awareness of $H$ parainfluenzae as a cause of endocarditis is important because empirical antibiotic therapy, especially that chosen for post cardiac surgery cases, may not cover this organism. Delay and difficulty in isolation and identification of the organism is often experienced, leading to destruction of cardiac structure. Our case also exemplifies that the clinical response to appropriate antibiotic therapy may be slow. Lack of response to appropriate medical and surgical intervention should not be automatically considered as an indication of treatment failure or superadded infection. Advances in our understanding of the phylogenetic significance of $16 \mathrm{~S}$ ribosomal RNA and the development of PCR technology offer opportunities for both the identification and detection of the HACEK group of organisms.
We thank Dr M D Collins, Institute of Food Research, Reading, for his help in confirming the identification of the isolate by $16 \mathrm{~S}$ ribosomal RNA sequencing.

1 Scheld WM, Sande MA. Endocarditis and intravascular infections. In: Mandell GL, Douglas RG Jr, Bennett JE, eds. Principles and practice of infectious diseases. 3rd edn. New eds. Principles and practice of infectious diseases.

2 Black CT, Kupferschmid JP, West KW, Grosfeld JL. Haemophilus parainfluenzae infections in children, with the report of a unique case. Rev Infect Dis 1988;10:342-6.

3 Jemsek JG, Greenberg SB, Gentry LO, Welton DE, Mattox $\mathrm{KL}$. Haemophilus parainfluenzae endocarditis two cases and review of the literature in the past decade. Am $\mathcal{f}$ Med and review of the

4 Hamed KA, Dormitzer PR, Su CK, Relman DA. Haemophilus parainfluenzae endocarditis: application of a molecular approach for identification of pathogenic bacterial species. Clin Infect Dis 1994;19:677-83.

5 Lynn DJ, Kane JG, Parker RH. Haemophilus parainfluenzae endocarditis: A review of forty cases. Medicine (Baltimore) 1977;56:115-28.

6 Hand WL. Haemophilus species. In: Mandell GL, Douglas RG Jr, Bennett JE, eds. Principles and practice of infectious diseases. 3rd edn. New York: Churchill Livingstone, 1990:1729-33.

7 Geraci JE, Wilkowske CJ, Wilson WR, Washington JA II. Haemophilus endocarditis. Report of 14 patients. Mayo Clin Proc 1977;52:209-15.

8 Lutwick LI, Gradon JD, Chapnick EK, Hakim A, Benkel MM. Haemophilus parainfluenzae endocarditis treated with vegetectomy and complicated by late, fatal splenic rupture. Pediatr Infect Dis 1991;10:778-81.

\title{
Primary extramedullary plasmacytoma of the liver
}

\author{
B Demirhan, C Sökmensüer, H Karakayali, Y Güngen, A Doğan, M Haberal
}

Departments of Pathology, Başkent University School of Medicine, Ankara, Turkey

B Demirhan

C Sökmensüer

Y Güngen

Department of

Surgery

H Karakayali

M Haberal

Department of

Histopathology, UCL

Medical School,

London

A Doğan

Correspondence to: Dr Beyhan Demirhan, Başkent Üniversitesi Tip Fakültesi, Patoloji ABD, Bahçelievler 06490, Ankara, Turkey.

Accepted for publication 30 September 1996

\begin{abstract}
Extramedullary plasmacytoma of the liver is a rare tumour, only two cases of which have been reported so far. A third case arising in a 22 year old woman, who presented with abdominal pain and enlargement of the liver, is described. Ultrasound and a computed tomography scan showed a solitary hepatic mass, $12 \mathrm{~cm}$ diameter, involving both lobes of the liver. Serum immunoelectrophoresis revealed an IgG $\kappa$ monoclonal gammopathy. Histologically, the tumour was composed of mature plasma cells with mild atypia. The plasma cells infiltrated the liver parenchyma and showed $\kappa$ light chain restriction. The monoclonal nature of the tumour was also demonstrated by PCR amplification of the immunoglobulin heavy chain genes. There was no evidence of bone involvement and repeated bone marrow aspirates and biopsy specimens were normal. The patient was treated with eight courses of chemotherapy. One year after diagnosis, the patient is well, the size of the tumour has decreased and the paraproteinaemia has disappeared.

(f Clin Pathol 1997;50:74-76)
\end{abstract}

Keywords: liver; extramedullary plasmacytoma.
Primary non-Hodgkin's lymphomas of the liver are rare. Many of these lymphomas are high grade, with only a minority of cases presenting as low grade tumours. ${ }^{1}$ A proportion of primary low grade lymphomas of the liver would seem to be B cell lymphomas of mucosa associated lymphoid tissue (MALT) type. ${ }^{2}$ To our knowledge, only two cases of primary extramedullary plasmacytoma of the liver has been reported to date. ${ }^{34}$ Here, we present a third case.

\section{Case report}

A 22 year old woman presented with a history of abdominal pain of four months duration. Physical examination was unremarkable except for moderate enlargement of the liver. Ultrasonographic examination and a computed tomography scan of the abdomen revealed a solitary hepatic mass, $12 \mathrm{~cm}$ diameter, which extended to both lobes. Haematological indexes were within normal limits but the erythrocyte sedimentation rate was $110 \mathrm{~mm} /$ hour. The patient was positive for hepatitis $B$ virus (HBV) surface antigen but was negative for antibodies against HBV surface antigen and hepatitis $\mathrm{C}$ virus. Liver function tests were within the normal limits. Serum protein electrophoresis showed increased $\gamma$-globulins, $58.7 \%$ (normal range 9-20). Serum immuno- 

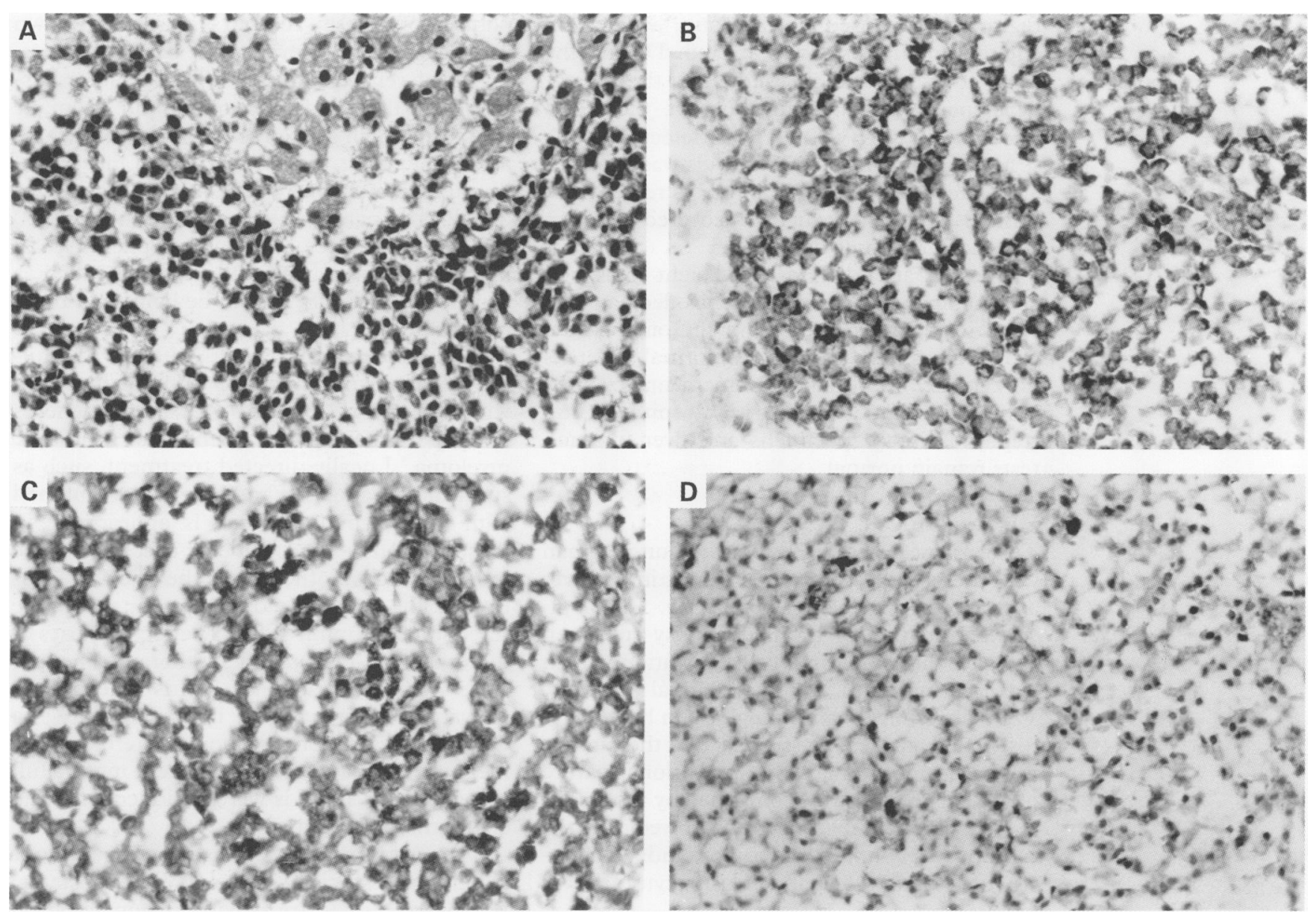

Figure 1 (A) Infiltrate of uniform mature plasma cells with mild atypia, invading the liver parenchyma (haematoxylin and eosin); (B) VS38 antibody positive cells (immunoperoxidase); (C) plasma cells showing $\kappa$ light chain restriction; (D) no $\lambda$ light chain immunoreactivity is evident.

electrophoresis revealed an IgG $(6080 \mathrm{mg} / \mathrm{dl}$; normal range $8-18) \kappa(6680 \mathrm{mg} / \mathrm{dl}$; normal range 5-18) monoclonal gammopathy. Urinary excretion of the $\kappa$ light chain was increased $(419 \mathrm{mg} / \mathrm{dl}$; normal range $10-18.5) ; \lambda$ light chain excretion was within the normal limits $(3$ $\mathrm{mg} / \mathrm{dl}$; normal range 0-5). Endoscopic examination of the gastrointestinal tract, skeletal radiographs and a bone scan were normal. A needle biopsy of the liver mass and bone marrow trephine biopsies were performed.

\section{Methods}

The biopsy specimens were fixed in $4 \%$ formaldehyde, embedded in paraffin wax and stained with haematoxylin and eosin and Congo red.

Paraffin wax sections $(4 \mu \mathrm{m})$ were studied immunohistologically using the streptavidin biotin peroxidase method. Trypsin treatment was used for antigen retrieval where necessary. The primary monoclonal antibodies used were directed against leucocyte common antigen (Dako, High Wycombe, UK), plasma cells (VS38; D Mason, Oxford, UK) and cytokeratin (Cam 5.2; Dako). Immunoglobulin light chain staining was done with polyclonal antibodies directed against $\kappa$ and $\lambda$ light chains (Dako).

PCR amplification of the immunoglobulin heavy chain gene was carried out on material scraped from the paraffin wax sections, as described previously. ${ }^{5}$
HISTOPATHOLOGY

Histological examination of the liver biopsy specimen showed a diffuse infiltrate of uniform mature plasma cells with mild atypia, invading and destroying the liver parenchyma (fig 1A). Portal areas were relatively well preserved. Immunohistochemical staining with the VS 38 antibody confirmed the plasma cell differentiation of the neoplastic cells (fig 1B), which also expressed leucocyte common antigen. Staining for immunoglobulin light chains showed $\kappa$ chain restriction (figs $1 \mathrm{C}$ and 1D). No centrocyte-like cells nor follicular structures were observed. Lymphoepithelial lesions were not found on careful examination of the slides stained for cytokeratin. No amyloid accumulation was detected.

PCR amplification of the immunoglobulin heavy chain gene revealed a single reproducible band, confirming the monoclonal nature of the plasma cells.

The bone marrow biopsy specimens showed mild erythroid hyperplasia but were otherwise normal. No increase in plasma cell numbers was observed.

\section{Clinical follow up}

In the light of the monoclonal plasma cell infiltration in the liver and in the absence of bone marrow involvement, the patient was diagnosed with a primary hepatic plasmacytoma. As the location and the size of the lesion permitted neither complete resection of the tumour nor radiotherapy, a chemotherapy 
regimen, comprised of vincristin, adriamycin and dexamethasone, was started. During the third course of the chemotherapy the patient developed acute re-activation of the $\mathrm{HBV}$ infection and HBV DNA was detected in the serum. Administration of steroids was stopped, after which the liver function tests returned to normal and the patient recovered without evidence of chronic disease.

One year after diagnosis and eight courses of chemotherapy, the liver mass has decreased to $7 \mathrm{~cm}$ in diameter and serum IgG and $\kappa$ light chain values have returned to normal. There is no evidence of bone involvement on repeated bone scans and bone marrow aspirates, and trephine biopsy specimens and liver function tests remain normal.

\section{Discussion}

The patient described here is a young woman who presented with a solitary mass in her liver and monoclonal paraproteinaemia. Histological examination of the liver biopsy specimen revealed diffuse plasma cell infiltration, which was reactive with the monoclonal antibody VS38 and showed immunoglobulin light chain restriction, suggesting strongly that the tumour was a plasmacytoma. The monoclonal nature of the plasma cells was confirmed by molecular studies. Clinical investigation showed that the tumour was confined to the liver and a diagnosis of primary hepatic plasmacytoma was made.

So far, only two cases of primary hepatic extramedullary plasmacytoma have been reported. ${ }^{34}$ Secondary involvement of the liver by non-Hodgkin's lymphoma is commonly seen in stage 4 disease; however, primary nonHodgkin's lymphomas of the liver are rare. Less than 100 cases have been reported to date. ${ }^{6}$ Limited information is available about the histological subtypes of primary lymphomas of the liver. Most seem to be high grade B cell neoplasms. ${ }^{6}$ Recently, four cases with the histological characteristics of low grade B cell MALT lymphomas have been described. ${ }^{7}$ It is possible that the high grade lymphomas also arise from MALT, although at present there is no evidence to substantiate this. ${ }^{6}$ Anthony et al have reported nine cases of small cell $\mathrm{T}$ cell lymphomas of the liver. ${ }^{1}$ A more recent study on $\mathrm{T}$ cell rich B cell lymphomas of the liver has suggested that some cases reported in earlier papers many also be included in this category. ${ }^{8}$

The histological diagnosis of solitary plasmacytoma of the liver should be relatively straightforward, if the tumour is composed of sheets of well differentiated plasma cells. The differential diagnosis is largely restricted to the plasma cell rich variant of the inflammatory pseudotumours of the liver. The absence of spindle cells, histiocytes and lymphocytes between the plasma cells is suggestive of plasmacytoma ${ }^{4}$ and using immunohistochemistry and molecular studies, the monoclonal nature of these tumours can be shown unequivocally. However, if the tumour is composed of relatively poorly differentiated plasmablasts, then a distinction should be made from other high grade B cell lymphomas which also show light chain restriction and clonal immunoglobulin heavy chain rearrangements. The lack of pan B cell antigens such as CD20 and the presence of immunophenotypical markers of plasma cell differentiation, such as expression of VS38, should be helpful in these instances.

About one third of patients with extramedullary plasmacytomas develop multiple myeloma within five years. ${ }^{9}$ After 10 years, most patients develop either a recurrence or multiple myeloma. ${ }^{4}$ Locally directed treatment, such as surgical resection or radiotherapy combined with long term follow up, is appropriate in these patients. The patient described here underwent chemotherapy as the size and location of the tumour did not permit complete resection or administration of effective doses of radiotherapy. During chemotherapy, the patient developed acute hepatitis due to reactivation of latent HBV infection. This is a well recognised complication of steroid treatment in HBV carriers. ${ }^{10}$ The patient made a full recovery after steroids were excluded from the chemotherapy regimen.

The primary hepatic plasmacytoma in our patient was associated with HBV carrier status. A number of extra-hepatic haematological malignancies in HBV infection have been described. However, any direct evidence suggesting that HBV infection could lead to the development of haematological malignancies is still lacking.

We thank $\mathrm{Mr} \mathrm{T}$ Diss for help with PCR analysis and $\mathrm{Mr} \mathrm{K}$ Miller for immunohistochemistry.

1 Anthony PP, Sarsfield P, Clarke T. Primary lymphoma of the liver: clinical and pathological features of 10 patients. 7 Clin Pathol 1990;43:1007-13.

2 Isaacson PG. Gastrointestinal lymphoma. Hum Pathol 1994; 25:1020-9.

3 Dohy $H$, Abe T, Takata N, Fujimura K, Taketomi $Y$, Kuramoto A, et al. Successful hepatectomy for solitary plasmacytoma. $N$ Engl $\mathcal{F}$ Med 1979;24:1218-19.

4 Weichhold W, Labouyrie E, Merlio JPh, Masson B, Mascarel A. Primary extramedullary plasmacytoma of th liver. A case report. Am $\mathcal{F}$ Surg Pathol 1995;19:1197-202.

5 Diss TC, Peng H, Wotherspoon AC, Isaacson PG, Pan L. Detection of monoclonality in low-grade B-cell lymphomas using the polymerase chain reaction is dependent on primer selection and lymphoma type. f Pathol 1993;169: 291-5.

6 Wright DH. Involvement of the liver by lymphoreticula disease. In: Millward-Sadler GH, Wright R, Arthur MJP disease. In: Millward-Sadler GH, Wright R, Arthur MJP,
eds. Wright's liver and biliary disease. London: WB eds. Wright's liver and

Saunders, 1992:1 138-54.
Isaacson PG, Banks PM, Best PV, McLure SP, Muller HerIsaacson PG, Banks PM, Best PV, McLure SP, Muller Her-
melink HK, Wyatt JI. Primary low-grade hepatic B-cel lymphoma of mucosa-associated lymphoid tissu (MALT)-type. Am $\mathcal{F}$ Surg Pathol 1995;19:571-5.

8 Khan SM, Cottrell BJ, Milward Sadler EH, Wright DH. T-cell rich B-cell lymphoma presenting as liver disease. Histopathology 1993;23:217-25.

9 Holland J, Trenker DA, Wassermann TH, Fineburg B. Plasmacytoma. Cancer 1992;69:1513-17.

10 Yoshiba M, Sekiyama K, Iwabuchi S, Takatori M, Tanaka Y, Uchikoshi T, et al. Recurrent fulminant hepatic failure in an HB carrier after intensive chemotherapy. Dig Dis $\mathrm{Sci}$ an HB carrier af 